\title{
El Proyecto Internacional de Poesía Gráfica o la poesía como trampolín
}

Diego Vadillo López

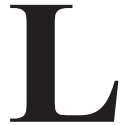
a poesía ha sido considerada a lo largo del tiempo, sobre todo desde el periodo romántico como el género por excelencia para expresar los más íntimos e inescrutables sentimientos, y pese a que ya Aristóteles la sometía a determinadas reglamentaciones, corroboradas y ensalzadas por la Ilustración, dichas "constricciones" teoréticas han sido también trascendidas no pocas veces; la más radical sería la remozadora actualización llevada a cabo por las vanguardias históricas, en las que se entremezclarían poéticas, disciplinas, géneros...

Además de para expresar sentimientos, la poesía es una vía para compartir dichos sentimientos a través de la puesta en común de determinadas creaciones, no en vano la poesía es un género literario que se ha venido mostrando muy apropiado para albergar antologías realizadas desde el más variado abanico de motivaciones. Asimismo, la historia ha consagrado a multitud de grupos y generaciones de poetas, algunos algo forzados por el interés historiográfico de la crítica, y otros por haberse fraguado férreos lazos fraternales entre creadores a través de la poética actividad. Por ejemplo, los más celebrados y revisitados miembros del 27 desarrollaron en unos $u$ otros momentos intensos vínculos amistosos, ejerciendo algunos de ellos, incluso, la crítica de la obra de otros, y viceversa. Precisamente el 27 fue un grupo no solo conformado por vates, sino por creadores de otras disciplinas artísticas e intelectuales, de ahí que no se abstrayesen de trasvasar elementos, verbigracia, de la música o la pintura a la poesía, es más, disciplinas como las mencionadas contribuyeron a dotar a la obra poética de estos escritores con un mayor fuste y poder de sugerencia.

Salvando las distancias, algo semejante ha sucedido con el Proyecto Internacional de Poesía Gráfica, una aventura que llevamos a cabo un grupo de creadores líricos a instancia de otro plástico. La poesía supuso aquí una vez más el trampolín que nos impulsó a compartir un designio común concebido desde la suma de las más variopintas individualidades, humanas y literarias.

Cuando el artista plástico Tudor Serbanescu me propuso emprender el proyecto gráfico-literario en realidad estaba haciendo un guiño a la historia de ambas disciplinas, las cuales desde muy antiguo han emparentado a lo largo de una dilatada tradición formalista que llega a nuestros días: desde, por ejemplo, la technopaignia (término acuñado por Ausonio en el siglo IV 
d. C. que significa "juego de arte") hasta los caligramas de Apollinaire...

Nada nuevo bajo el sol. En este punto de la historia de la humanidad todo ha sido hallado y practicado, ergo no se trataba de presentar un plan novedoso, sino más bien de, haciendo uso de fórmulas de colaboración interdisciplinar con no pocos precedentes, mostrar mediante una doble interpretación lírica cómo el ingenio se filtra por los más impensados vericuetos. Desarrolla, al fin, Serbanescu plásticas metamorfosis de los poemas, obteniendo unos "ideogramas" que vienen a ser reinterpretaciones lírico-gráficas de los poemas, que asimismo son interpretaciones de cuitas o intuiciones. Por ello, lo que ofrece el Proyecto Internacional de Poesía Gráfica es una doble interpretación lírica, la literaria-primaria y la visual-secundaria, si bien es cierto que en la secundaria, Serbanescu ha aportado no poco de su propia cosecha creativa.

Del conjunto se deriva una armoniosa y plástica danza acústico-visual en la que las formas resultantes conforman un conjunto que integra los dos lenguajes en solfa de una manera harto insinuante.

Si en el título del presente artículo, tras la conjunción disyuntiva, comparaba a la poesía con un trampolín, lo hacía porque precisamente se me antojaba el último vocablo una fórmula muy gráfica para expresar el resorte impulsor que ha supuesto la poesía hacia dos evidencias constatables con la perspectiva que nos otorga la finalización de la aventura: por un lado hacia el diálogo interdisciplinar, y por otro hacia la fraternal intercomunicación entre los poetas participantes. No solo queda un libro como testimonio del recorrido intercontinental que ha supuesto el proyecto, sino un montón de lazos de amistad y de diversas colaboraciones en revistas y acciones de diverso tenor. También los artículos y críticas realizados por muchos de los miembros del grupo sobre lo común y sobre la obra de otros miembros. Además, en los eventos, los poetas que participaban en unos u otros, según el país, recitaban poemas de los restantes miembros ausentes, lo que suponía una reseñable sobreposición al ego, tan presente siempre en los poéticos cenáculos.

América, Europa y Oceanía quedaron representados en el proyecto, y los participantes son los siguientes: Beatriz Rastaldo (Argentina), Tales Jaloretto (Brasil), Maggy Gómez Sepúlveda (Colombia), Rita Valencia Saldivia, Luis Arias Manzo (Chile), Alexander Anchía Vindas (Costa Rica), Alba Azucena Torres (Nicaragua), Blanca del Valle, Ana Jiménez Herrero, Diego Vadillo López (España), Domnita Neaga, Elisei Virgil, Tudor Serbanescu (Rumanía), Dusica Nikolic Dann (Serbia) y George Roca (Australia).

La poesía de todos los intervinientes justo aquí arriba referidos es personal y heteróclita; pese a existir algunas ciertas concomitancias entre algunos de ellos, las voces son fácilmente discernibles, así como la plasmación gráfica de las piezas, no en vano, gran parte de la crítica ha apuntado que el desmadejamiento de los rígidos parámetros métricos ha entronizado una laxitud a tal respecto que vendría a responder a los impulsos del alma del creador lírico. Así las cosas, tenemos en la antología Poesía 
Gráfica (Rotipo, Iasi, 2016) desde los breves e insinuantes poemas de Elisei Virgil hasta los más morosos y discursivos de Álvaro Torres Calderón o de Rita Valencia.

Hay voces eminentemente románticosentimentales, como la de Alba Azucena Torres, que funda gran parte de su creación poética en el recuerdo, un recuerdo casi siempre de índole sentimental. Acostumbra a desplazarse a entornos exóticos y suntuarios por entre los que vela y revela al tiempo las más intensas remembranzas:

\section{Ángel marino}

Es ámbar tu mirada cristal cortado cuarzo cuando yaces en la arena de algas arropado arrojado del paraíso, endeble llanto y risas anidan en tu cuerpo besado por la espuma agujereado de caracolas. inerte y vuelto al vacío.

Por su parte, Luis Arias Manzo dota de una impronta más espiritual a sus piezas: "Se me fue entre los dedos la vida/ y he vuelto a nacer junto a ti", escribe en "¿Hace cuánto nací?”. Asimismo, Arias Manzo hace uso de unos recursos retóricos harto encandiladores, veamos algunos ejemplos del poema "Un largo día sin ti": por ejemplo, hace uso de la prosopopeya "sentí llorar a los pájaros", de la greguería "La tierra muge en las cuchillas del arado", de la sinestesia "Hoy se destiñen los recuerdos viejos" y termina con la clara expresión de la fusión del poeta con la otredad:
"He olvidado mi nombre/ y el mundo que existe fuera de nosotros".

Alexander Anchía entremezcla junto a otros temas el amor erótico-pasional y la metapoesía, estos son los dos más recurrentes asuntos en su obra poética. Canta ora jubiloso, ora resignado al amor (por ejemplo en "Adiós a mis muñecas"), y canta ora esperanzado, ora desalentado a la poesía y a sus auspiciadores: "escasean los poetas/que lean en un te amo/ escondido en la ola/ de un surfeador", escribe en un poema cuyo título coincide con el primer verso de los aquí traídos, los cuales conforman una hermosa estrofa que, a su vez, sustenta una imagen de gran audacia y profundidad.

George Roca es también un poeta direccionado en la mayor parte de su poesía hacia un tú desde el sentimiento romántico-sentimental. Se expresa en un hondo y simpático petrarquismo que recurre a las más insólitas imágenes. "Abrazo", por ejemplo, porta elementos de las vanguardias históricas (matices futuristas, surrealistas...), si bien el conjunto termina en una convencional unión sentimental o en el deseo de esta:

\section{Abrazo}

Si te encontrase

te convertiría

en un avión.

Tú, para complacerme abrirías tus brazos y flotarías suavemente hacia mí. 
Yo...

me convertiría en un pájaro

y, acercándome a ti,

entretejeríamos nuestras alas

en un abrazo de alma y cuerpo

acariciándonos tiernamente

hasta que sintiéramos

la simbiosis de nuestro amor...

También hay mucho espacio para la nostalgia en la poesía de este autor, añoranza de los paisajes de la infancia, de la tierra dejada atrás; un ejemplo paladino es su poema "Nostalgia", precisamente.

Beatriz Rastaldo es una afinada e intuitiva versificadora que acostumbra a establecer una sublimidad de lo cotidiano en sus poemas. Desde el mobiliario más accesible asciende hacia cotas de inefabilidad conmovedoras. Como botón de muestra traemos unos versos de su poema "Era... Es... Será...": "Es el mismo amor/ que me abraza/ en sueños/ cuando el desamparo/ me viste frágil".

Posee también la poesía de Maggy Gómez Sepúlveda un marcado tono sentimental, con la característica aparejada de portar una susurrante textura. Es la suya una poesía fragante y sensorial que envuelve al lector en el arrobo de su hálito. "Extraño", por ejemplo, es un poema en el que lo sensorial marca la pauta, véase en el siguiente extracto: "Me falta tu mirada,/ el aroma de tu $\mathrm{piel} / \mathrm{y}$ el sonido de tu caminar".

Dusica Nikolic Dann elabora una poesía muy cercana estilísticamente a la de Alba Azucena Torres, en cuanto que invoca remembranzas de manera sutilmente estetizante y a que aderezada cada pieza con un insinuante manto de ciertas alusiones culturalistas así como imágenes de gran fuste e intensidad:

\section{Bajo el sol ardiente}

Bajo el sol ardiente de la antigua Grecia una joven ha roto el jarrón.

Siglos después, coleccionistas de antigüedades se llevaron los pedazos de tierra tostada a todas partes del mundo.

Mientras bajo el sol grande de Grecia por siempre quedó una grieta, línea curva de dolor, que nadie compró.

Domnita Neaga entrevera en sus composiciones muy diversos ingredientes rociados todos por un sutil condimento de tamizado surrealismo. El paso del tiempo, el desamor, la soledad son transitados sin gravedad, con una serena mirada irónica que deja de fondo un guiño a la esperanza. Se dirime en sus versos con frecuencia lo difícil de la convivencia en pareja, los altibajos, los estados de ánimo variables... En "Tu sombra" quedan claras tales cuitas internas: "Te quiero; después de tanto tiempo/ tu amor me abraza como una enfermedad;/ un miedo loco/ por mis huesos se licúa/ cuando tengo en mis brazos/ tu suave sombra, proyectada/ por un rayo lunar [...]".

Es la poesía de Elisei Virgil muy introspectiva y un tanto críptica, pues dosifica este poeta muy bien las sílabas que expresan sus internas cogitaciones. Invitan a la lectura sus piezas y a la vez evitan que el lector termine con una clara idea de las ideas 
del versificador allí plasmadas. Sus poemas son estados, (así se titulan, "Estados") y el autor aprovecha el caudal de asimilación de la inefabilidad consustancial a ciertos sentimientos para trasvasar al poema esos estados internos no fácilmente elucidables.

\section{Estado X}

Soy

totalmente

transparente.

Una garra,

con el contorno

y el galope

de un caballo

recorre

$\mathrm{mi}$

interior.

Un enlace

que del pie

izquierdo cojea

se mofa

de un miope

que mira a la

nada.

La poesía de Rita Valencia Saldivia accede a la expresión de ciertas insatisfacciones más proyectadas hacia lo mundano que hacia el molturado interior. Son sus versos morosos y ricos en detalles. Lo descriptivo-narrativo es magistralmente armonizado con los más finos lances de lírica capacidad de sugestión. Las internas insatisfacciones son trasladadas con simpar pericia poética, rociados con una dulzura que no logra atemperar el fondo discursivo de lo referido, como en el siguiente pasaje de "Vestigios": "El sabor a sinsabor/ de los desiertos del alma,/ los áridos territorios/ de la resignación.// Hay tiempos que no saben a nada.../ Las palabras que nunca llegaron./ Esos sueños que se rompieron,/ el hoy no es como ayer./ El amor no correspondido, la urgencia del instante inmediato./ Vestigios de todo y de nada.// Hay tiempos que no saben a nada".

En línea semejante a Valencia, Álvaro Torres Calderón, elabora una poesía con tintes más mundanos, incluso acercándose a lo social, como en "Clan(destino)", poema en el que juega con lo duramente mundanal trascendiéndolo mediante audaces y bellas fórmulas poéticas, como en el siguiente pasaje del mencionado poema: "No se deja registro en el libro de los amores./ Y el supervisor de la oficina de migraciones del amor/ es ciego y a veces se olvida de sentir./ Lo que muchos no saben es que/ es el que ama intensamente toda/ la vida".

La inconmensurabilidad también es frecuentada por Torres Calderón, así como la evocación a la amada a través de insinuantes emplazamientos: "Mi alma me dice que no hay espacios sin que los pintes tú/ y puedo alcanzar aquella feliz estrella que me saluda/ e invita a sentarme en sus faldas de luz".

La de Ana Jiménez Herrero es una poesía desnuda de ardides y henchida de sentimiento a flor de piel, si bien puesto de manifiesto con suave temperamento evocativo. Refiere con cierta recurrencia nuestra poeta el hiato entre el deseo más ferviente y las barreras impuestas por una realidad que tantas veces imposibilita la materialización de las más íntimas aspiraciones. 


\section{Dos almas}

Digno brote de su hacedor, dos almas que nadie entiende, una se quedó con él y la otra, viajera, lo espera.

Calmada tormenta en sus ojos, que luego plasman sus manos con colores de la vida, con figuras de lamento.

Él quiere estar con nosotros, pero se lo impide el viento.

Blanca del Valle es una poetisa que teje magníficas piezas líricas con la melancolía y la tristeza como mimbres principales. Un suave escepticismo, el propio de una trayectoria vital sensible y con poso es el que fluye por entre las estrofas de cada uno de sus poemas.

La vida, en sus flancos más existenciales, es escrutada de manera líricamente discursiva por Blanca del Valle, que despliega un tono sencillo y directo, así como pulcro. Reflexiona nuestra poeta entregándonos sus cuitas en ingeniosas aseveraciones que recuerdan por momentos a las humoradas de Campoamor. La gravedad es trasladada por Blanca del Valle con sencillez y un cierto humorismo tamizado que nos resarce en última instancia de la debacle.

\section{Removiendo}

Si al remover el cieno

apesta y huele,

al remover la tierra

se la cultiva.

Por eso el revoltoso,

que anda buscando

con su azada, cultiva

lo bueno y malo.
Queriendo dañar al árbol

yo una rama le corté;

yo quería hacerle daño

y le hice mucho bien.

Tales Jaloretto, como artista multidisciplinar, confiere a su poesía tintes de inverosimilitud, jugando con los ritmos y los espacios tipográficos de manera tan desconcertante como sugerente. Juega y se recrea en las aliteraciones, en las paronomasias, en las recurrencias anafóricas, los juegos antitéticos, los calambures, las paráfrasis, las jitanjáforas... Si bien por entre la exuberancia retórico-tipográfica se abren paso profundas reflexiones.

\section{$22 \mathrm{~h} 22$}

Corazones difusos disonantes.

En fusos consonantes, Corazones.

Constantes Corazones confusos.

"Si nada nos salva de la muerte,

al menos que el amor nos salve de la vida".

Llegados a este punto del recorrido por la poética de los poetas pertenecientes al Proyecto Internacional de Poesía Gráfica, quedaría únicamente por glosar el que estas líneas escribe, y como me parece feo teorizar sobre uno mismo, incluiré unos apuntes que el también poeta José Luis Pérez Fuente escribió no hace mucho sobre mi quehacer en tales lides: "El poeta que Diego Vadillo lleva dentro es un ludópata de la palabra, un jugador empedernido del verbo hecho metáfora. Dotado de gran capacidad de observación, que transforma la realidad en paisajes de palabras y crea collages ideográficos en sus versos, transformándose en imágenes surrealistas, subconscientes, cuando el lector las hace 
suyas" (cf. en "Apuntes acerca de La bruma consternada de los días. Poesía reunida, de Diego Vadillo López, Azay Art Magazine, nº 6, abril de 2017, pp. 10-17). Uno de los poemas con que participé en el proyecto fue el que sigue:

\section{Nostalgias}

Nostalgia florece en mantillos de tiempo libre, bajo estiércoles de ingrávida rutina azul.

El rencor es su cara cenicienta.

Rencor es la urticaria que le sale al recuerdo.

No hay nada como orear el espíritu... e inaugurarse.

Tras el recorrido definitivo por la nómina de participantes, solo queda apuntar que, a tenor de las consideraciones recibidas de los copartícipes vates y del entusiasmo con el que muchos de ellos organizaron eventos que obtuvieron gran eco, la poesía fue erigida trampolín que nos ayudó a impulsar el espíritu más fraternal, ya que, siendo la susodicha poesía el leit motiv de la iniciativa, a través de ella no solo se abrieron paso interesantes voces para hacerse escuchar allende lo que pudiéramos haber imaginado, sino que sirvió, asimismo, para forjar lazos de concordia y amistad entre gentes de distintas localizaciones geográficas dueños de sus respectivos planteamientos humanos y literarios.

En un mundo inconmensurable, la poesía transitó planetariamente aupada por una serie de voces a las que a su vez impulsó. Fue elemento expresivo y cemento cohesivo e integrador de las diversas sensibilidades a las que nos hemos referido en este artículo recordativo. 
